\title{
An ICT Tool in a Rural School: A Drawback for Language Students at School?1
}

\section{Una herramienta TIC en un colegio rural: ¿Un inconveniente para los estudiantes de idiomas en el colegio?}

\author{
Yehison Andrés Rojas Rojas ${ }^{2}$ \\ Institución Educativa San Isidro - Ümbita \\ yarking22@yahoo.com
}

Received: September 28, 2017

Accepted: December 4, 2017

How to cite this article (APA, 6th ed.): Rojas-Rojas, Y. (2018). An ICT Tool in a Rural School: A Drawback for Language Students at School?. Enletawa Journal, 11(1), 91-109

\begin{abstract}
Technology involves a vast number of advantageous usages that range from the sciences to the educational settings. Limited access to computers and the internet, among other factors, are a drawback, thus, creating a digital gap. Nonetheless, the panorama for the English as a Foreign Language (EFL) and the use of internet communication technologies (ICT) in Colombia is promising given the countless number of new resources found online. However, using ICT tools requires not only the teacher's attention, but also governmental aid before they can be implemented in the EFL class. The scope of the ICT tools in the rural setting is vast and has a great impact on students. Therefore, if factors, such as equipment in decent conditions,

1 Reflective Paper

2 Yehison Andrés Rojas Rojas holds a B.A in Foreign Languages from Universidad Pedagógica y Tecnológica de Colombia and is a student in the Master's Program in Language Teaching. He currently teaches English as a Foreign Language at Institución Educativa San Isidro de Úmbita. He has worked as an English professor at Universidad de Boyacá and Universidad Pedagógica y Tecnológica de Colombia. He has been an English advisor instructing English as a Foreign Language in different institutions in town.
\end{abstract}


updated applications, and training, are not provided the real amplitude of these tools cannot be measured.

Key words: Rural Education, EFL teaching, ICT drawback, ICT Policy for EFL

\section{Resumen}

La tecnología implica una gran cantidad de usos favorables que van desde las ciencias hasta los entornos educativos. No obstante, no solo el acceso a internet es el inconveniente de la brecha digital. Por lo tanto, el panorama para el inglés como lengua extranjera (EFL) y el uso de las Tecnologías de la información y la comunicación (TIC) en Colombia es prometedor, debido a los innumerables nuevos recursos encontrados en línea. Sin embargo, el uso de herramientas TIC en la enseñanza requiere no solo la atención de los docentes sino también del gobierno antes de que puedan implementarse en la clase de EFL. El alcance de las herramientas TIC en el ámbito rural es amplio y tiene un gran impacto en los estudiantes. Por lo tanto, si escenarios tales como equipos en condiciones decentes, aplicaciones actualizadas y capacitación, no son garantizadas, la verdadera amplitud de estas herramientas no se puede medir realmente.

Palabras clave: Educación rural, enseñanza de inglés, desventaja de las TIC, política de TIC para la enseñanza de inglés. 


\section{Introduction}

Due to the advent of new technology, a vast number of advantageous usages can be counted, ranging from science to entertainment to education. Despite the fact that many users are frequently downloading and using contents from and on the web, there is a disadvantage for those living in rural settings. Such parts of the country suffer from a lack of adequate internet connection, as well as limited access to computers. This is because large cities tend to have more options for connectivity, and consequently, can benefit more from the easy and fast availability of technology (El Tiempo, 2017).

The digital divide is understood as the lack of access to the internet. Servon (2002) mentioned "the very existence of the 'digital divide' or lack of access to it for certain segments of the population..." (p. 1) is directly related to the way technology facilitates the access to education in distant places. It is well known that if there are places where technology is unreachable, people living in those surroundings will lack the best conditions available to communicate with the world and obtain meaningful experiences. Kàrpàti (2011) said that this was a key issue in regard to the use of ICTs in education. She argued that "Students can access information more easily, as a growing amount of data is available in digital repositories that are much easier to access than traditional, paper-based resources for learning" (p. 4). Nevertheless, access to the internet is not the only drawback to the digital gap. It is necessary to think about training teachers and students in Digital Literacies ${ }^{3}$, as they are the ones directly benefited from ICTs in the educational settings.

English as a Foreign Language is a relevant subject in the Colombian context. As Bonilla and Tejada (2016) mentioned:

Several countries aiming at their economic and scientific growth, like Colombia, have chosen English as the official foreign language, standing as a subject alone with no evident linkage with the rest of the curriculum that is taught in the L1. (p. 193)

The Colombian government has chosen English as the language meant to fulfill the bilingual component. As a consequence, it is necessary to achieve the law and regulations stipulated by the government in terms of bilingualism. Hence, the panorama for English as a Foreign Language (EFL) and the use of ICT in Colombia is promising. This is because there are countless new resources that can be found online and adapted for each class as complementary activities for language learners. However, in rural areas where the budget to purchase materials is scarce, the use of ICTs is limited. Ramos and Aguirre (2016) agreed that "Wherever and whenever possible, it is ideal to have a Learning Resource Center, since it has been proven that students do improve after they have used this kind of resource" (p. 217). Although these practices give an

3 Digital literacies comprises a set of basic skills which include the use and production of digital media, information processing and retrieval, participation in social networks for creation and sharing of knowledge, and a wide range of professional computing skills (Kàrpàti, 2011). 
account of the use of technology in the EFL area, at the same time they promote digital literacy in students who had not been able to use computers just a few years ago. Ramos and Aguirre (2016) demonstrated how the implementation of ICTs in rural schools could help in the adequacy of new technologies.

The case in Colombia is not much different than that of other countries who are trying to become the most educated around the world. As a matter of fact, Colombia has worked on many policies that promote the use of ICTs in the country. This assignment is done by the Ministry of Communication and Technologies (hereafter MinTIC), in which the Minister himself is in charge of the direction, design, adoption and promotion of policies, plans, programs and projects related to Information and Communication Technology Sector (MinTIC, n.d.). However, it is necessary to consider certain factors, which implicate not only teacher's attention but governmental commitment, before these tools can be fully implemented in the EFL classroom. These factors are also related to external issues that limit the use of ICTs, and not so much to the ability of teachers to cope with technology. Padilla, Vega, and Rincón (2014) stated that "The technological mediations, as well as all their potential, are associated with the need for a fast and stable Internet connection, in addition to problems derived from the security of information and the authorship of productions" (p. 287) ${ }^{4}$.

The work that motivated me to do this reflection was grounded in the

4 Translation done by the author for publication purposes. situations I have seen in developing a seminar activity for the M. A. in Language Teaching at the Universidad Pedagógica y Tecnológica de Colombia. The project was carried out at public schools, and the main objective was to engage school students to use a specific webpage (storyboardthat.com, see Image 1) within and out of the classroom. This was done as a way for students to learn how use the webpage, but at the same time, as a means to engage students in the EFL learning process. The project took place in two different public schools. One of the schools was an urban school located in Cimitarra, Santander. There, internet access was granted some time before the starting of the project. Having internet was a great advantage for the teacher and students because they had the chance to use the web-page proposed in their class. The difficulty was that electricity was not consistent in town, and there were many cuts off at any given time.

In contrast, according to MinTIC, there are 13 "Kioskos Vive Digital" (henceforth, KVD) located in schools around the municipality of Úmbita, Boyacá. These KVD are supposed to grant internet service and connectivity for the municipality and its surroundings. Although, the school where the project took place had internet access, it did not have an active KVD. Conversely, its internet service was not constant, and students did not have the opportunity to make use

5 According to MinTIC "KVD are community internet access points for children, youth and adults in rural areas of more than 100 inhabitants, located in the most remote areas of Colombia" (MinTIC, 2018). Retrieved from http://colombiatic.mintic.gov.co/679/w3propertyvalue-36365.html 
of the internet frequently. However, it was possible to manage some time to schedule some sessions and teach them how the web-page worked. In doing so, they could continue with the activities proposed when internet access at school would allow it or at an accessible internet service in town.

When developing the activities on the webpage, it was evident that there were technical failures. In addition, the difficulties were associated to connectivity issues that limited the ability to work on the activity most of the time. The time that students devoted was not sufficient to learn how to use the interface of the webpage, which was not familiar to them, even if there was a chance to work at a KVD.

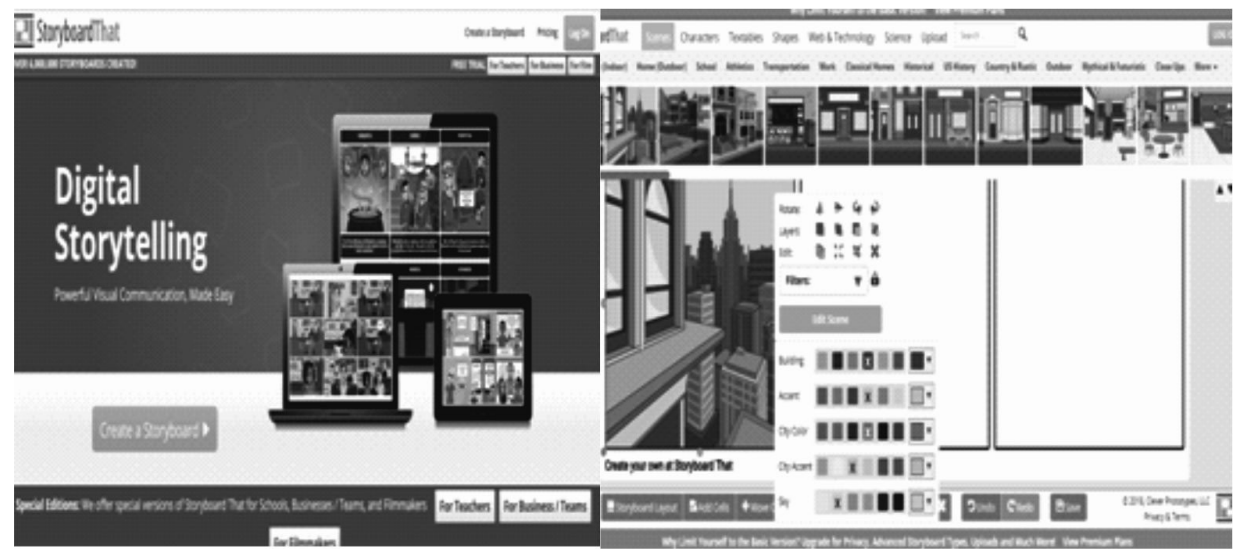

Image 1. Home page (left) and activity display page (right) of the webpage www.storyboardthat.com

On that note, there are concerns which make me query about the real amplitude of ICTs in rural schools. One of them deals with the use of ICTs for the foreign language classroom and the possibility ofICTusebecominganational policy in education. Another concern is regarding the government programs that promote the use of technologies in the country. As a requirement and obligation, equipment at schools must be maintained so as to provide the best usable conditions. Antivirus, software and basic application updates must be done regularly at each school. In the following pages, the reader will find an explanation of the digital plan in
Colombia, its relation to rural education and connectivity, the uses of ICTs, and the inclusion of the foreign language. Afterwards, a perspective is included on how the schools in the previous project had dealt with the difficulties in the implementation of technology. Finally, I conclude with a summary of the previous topics mentioned above.

\section{Colombian Digital Plan}

Law 1341, Article 39 of 2009 decrees that "The Ministry of Information Technologies and Communications will coordinate the articulation of the 
ICT Plan, with the Education Plan and the other sectoral plans, to facilitate the concatenation of the actions ${ }^{6 \prime \prime}$ (Congreso de la República, 2009). In addition, the government seeks to use ICT as a tool to achieve wide coverage around the country. As an example, the national development plan for Colombia, PND due to its name in Spanish, states:

Additionally for the education sector, the National Development Plan for Colombia, PND due to the Spanish acronym, establishes that the National Government will consolidate ICT as a technological platform to improve the coverage, quality and relevance of educational processes, promote the generation and use of educational content, as well as access to ICT through the connectivity of the official educational venues, the development of content, the replacement of equipment, the support and maintenance of the same. (Departamento Nacional de Planeación, 2013, p. 4$)^{7}$

As seen here, the involvement of the MinTIC, as a leader of ICT policies in education, understands ICT as a support for educational processes. The goal of this action is to foster ICT use at schools. However, to be able

6 Translation done by author for publication purposes.

7 Additionally, for the education sector, the National Development Plan (PND) established that the national government will consolidate ICT as a technological platform to improve the coverage, quality and relevance of educational processes, promote the generation and use of educational content, and facilitate access to TIC through connectivity from official educational centers. Furthermore, the development of content, the replacement of equipment, and the support and maintenance of equipment would be done. to achieve this outcome, there is a need to cover most of the Colombian territory (MinTIC, n.d). ${ }^{8}$ As a result, MinTIC promoted the Plan Vive Digital grounded in the Plan Nacional de Desarrollo (2010-2014) ${ }^{9}$, whose objective was to encourage the massive use of the internet, the appropriation of technology, and the creation of new jobs as a way to reduce poverty, raise competitiveness, and provide equal opportunities in the country (MinTIC, 2015).

Clearly, the government's objective is to implement the use of ICTs in the country as a means of granting opportunities to its citizens. All of this is to be done by approaching contents related to new knowledge that can be implemented in daily life. However, getting connected to the internet is not an activity that every citizen is able to perform, due to factors like age and economic conditions. For the most part, those accessing the internet are primarily young adults with their own devices. Datexco Company S.A. (2015) stated that " $76 \%$ of young people between 12 and 17 have their own mobile phone with voice and data" (p. 22).

Digital literacy has evolved in such a way that it has caught the attention of Information Technology Education since the term literacy is now a

8 The extension of the territory has a diverse population and demographics.

9 PND-National Development Plan for Colombia. It is the document that serves as the foundation and provides the strategic guidelines of public policies formulated by the President of the Republic through his government team. Retrieved from https://www.dnp.gov.co/PlanNacional-de-Desarrollo/paginas/qu-es-el-pnd. aspx 
synonym for competence. Lankshear and Knobel (2011) stated that "Concepts like 'being computer literate' or being 'technologically literate' are sometimes used simply to mean that someone is more or less proficient with a computer or some other device" (p. 21). Thus, digital literacies express how these new approaches to communication can help learn other subjects, specifically at school. Nonetheless, the ability to become digitally literate is something that affects matters personally. "In order to develop adequate 21st century skills among students, educators should be authentic ICT users and integrate digital literacy with other core competences in their professional and private lives" (Kàrpàti, 2011, p. 5). Consequently, the use of the new technologies not only permeates the educative stance, but daily personal activities as well.

According to Uribe and Machett (2010) "In Colombia, it is notorious that the information literacy training is not clearly seen as a key strategy in education, and research libraries" (p.18). This statement clearly demonstrates how online literacy training implemented in Colombia is targeted at only a specific group of people. This population includes school and university students who have taken some type of instruction at school and on campuses. In this sense, the government aims at taking ICTs to most of the Colombian territory, but it has forgotten that the inhabitants of these regions are digitally illiterate. This means that only people who are attending school or have had the opportunity to receive training related to Information Technology are at an advantage.
Back in 2001, rural schools showed up as having the highest number of drop outs, which could probably be linked to child labor (Ministerio de Educación Nacional [MEN], 2001a). This has been replicated generation to generation, and it explains why parents have a low education level. Mercado (2017) illustrated this by saying "Although access and coverage are guaranteed in primary school, once they obtain the fifth grade card there is a leak of 52 percent of the students." 10 The government promotes the use of ICTs, but there is a small amount of people who can truly take advantage of these technological resources. Students in these types of settings and conditions are not getting the adequate commitment needed to take advantage of these resources. Emphasis should be made on this issue because in the rural environment these percentages of students, who have disserted school, are the same ones who in the long term would benefit their communities with the use of new technologies. However, if there are few people learning how to use ICT, governmental efforts will not accomplish the coverage and productivity that is sought with new technologies.

In this case, a disparity is found in the implementation of projects. Populations residing in rural areas do not have a close relationship to the internet or the use of technology. As explained before, this is due to the fact that many students in these areas drop out, are focused on other activities that do not require ICTs, or simply, they do not get along with technology. Keeping in mind that the goal for the MinTIC is

10 Translation by author for publication purposes. 
that this specific population of young rural students make use of ICT tools, the MinTIC developed a project called Kiosko Vive Digital, which states the following:

The purpose of this initiative is to promote the supply of ICT services in rural and remote areas of the country, through the installation, commissioning, operation, maintenance and administration of Kioskos Vive Digital, in order to encourage the use of the same kiosks in the economic, social and cultural processes of these regions. (Departamento Nacional de Planeacion, 2013, p.17) ${ }^{11}$

Clearly, the project aims at solving shortcomings in terms of connectivity in distant places, such as rural areas, where once again there is a limited population that can use the program. The objective of KVD is to assist the MEN and the local Secretaries of Education in granting connectivity. In this way, people living in rural areas will have internet connection to complete homework assignments and do research. Nevertheless, the current situation in such places is that the target population have not completed their full schooling cycle. Therefore, as Mercado (2017) observed, their knowledge about IT topics are limited.

Given the unfamiliarity to technology, they do not rely on these tools, and in fact, they prefer not to use them. To illustrate this idea, the Colombian government promotes the use of "Gobierno en Linea" (GEL), or on-line governmental services. Any Colombian

11 Translation by author for publication purposes. citizen living in a populated city with a standard penetration to the World Wide Web (WWW) has the possibility of doing government-type paperwork online, thus, avoiding the endless line. As Image 2 illustrates, there are many services and activities that can be done on the GEL webpage.

On the other hand, some people prefer going to the office or governmental institution to file their paper work. However, they are unaware of what Decree 0019 of 2012 stipulates, which is focused on "suppressing or reforming unnecessary procedures and regulations existing within Public Administration, in order to facilitate the activity of natural and legal persons before the authorities and contribute to the efficiency and effectiveness of these activities" (p. 2). Additionally, these regulations must be applied by:

All agencies and entities of the Public Administration sector that exercise functions of an administrative nature, under the terms of Article 39 of Law 489 of $1998^{12}$ and individuals when they perform administrative functions. (Decree 0019, 2012, Art 2).

The education sector, such as the Ministry of Education and the Secretaries of Education fall into this category. Therefore, the school setting is the ideal and appropriate scenario to begin teaching about ICTs.

12 Law that regulates rules on the organization and function of national entities in Colombia 


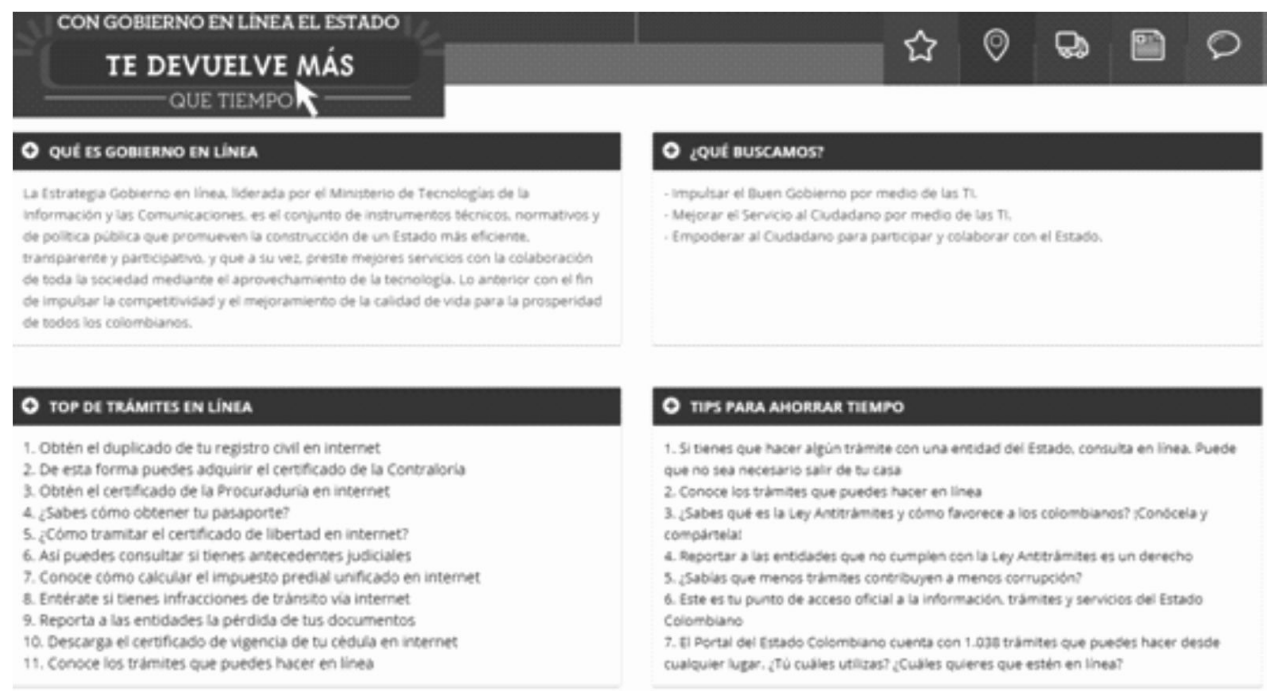

Image 2. GEL webpage exhibits administrative procedures done on-line.

\section{The panorama around the town}

Rural education displays difficulties that need to be recognized by policy makers. As mentioned by Barley and Brigham (2008) "In rural schools teachers are more likely to teach multiple subjects, making it less likely that they are highly qualified in some of the subjects they teach" (p.1). Colombia is not the exception to this situation. Rural teachers have to teach not only the classes they have been trained to do (social sciences, math, language, science, and others), but they also have to teach other subjects designated by principals in order to supply a demand for teachers in the rural settings (MEN, Decree 3020, 2002).

Burchett (as cited in Barley and Brigham, 2008, p. 2) mentioned that teachers working in the rural settings in the Central Region states ${ }^{13}$, had to

13 States from the northern central United States. prepare for more than four different subject classes. This fact can also be perceived in Colombia since teachers are asked to teach subjects that may fit their profile, given the high dropout rate in rural settings. In this sense, according to Bonilla and Cruz-Arcila (2014), "little attention has been paid to the ways in which foreign language teaching has been dealt with in rural areas or to the ways in which language teachers in these regions have made sense of what they do" (p. 118).

Although it is true that the national government has tried to create and promote English language teaching resources, such as the textbook series "Way to Go" and "English Please", the rural environment is relegated once again. This is because the content of these books refers to situations that students have not had the opportunity

Colorado, Kansas, North Dakota, Nebraska, Missouri, south Dakota and Wyoming 
to experience themselves. As a consequence, the personal connections they might have with the language are minimal. Similarly, the teacher modifies the content of these materials and uses them in the best way to ensure the learning of their students. Considering that these resources are not focused on students' needs, it takes teachers a considerable amount of time to prepare materials. It is important to mention that previous studies, such as Perfetti (2004) and Lakin and Gasperini (2004), set language learning in a difficult situation due to the poverty that people live there and that is still present today. As Bonilla and CruzArcila (2014) mentioned "Due to the fact that rural language contexts do not offer ideal conditions to learning a second language, teachers highlight the fact that very little is known about the national policies in their context" (p. 125). Consequently, ICTs can be a way to increase the possibilities of obtaining knowledge, despite the lack of materials in rural environments and the way in which teaching is modified in these environments.

Therefore, a solution for these educational settings was found in the implementation of the project Vive Digital and Kiosko Vive Digital. In the town where the rural school is located, students have more chances to connect to the internet since there is a "Punto Vive Digital" (henceforth PVD), which is the same as a "KVD" in urban settings. At this kiosk, a person is in charge of assisting users in connecting to the internet. This location allows students from urban settings to attend the PVD to surf the internet, do research, or simply play games on- line at any time. The PVD provides more chances for users to familiarize themselves with the display, content, and use of webpages thanks to the readiness, quickness and accessibility to the web through the PVD. These users do not have to take long walks to use these tools, unlike rural settings. In the case of rural zones, it is possible to find a KVD, but the service is limited due to diverse factors, such as absence of connection, hardware or assistance.

Teenagers and young adults most commonly use these services to look at social networks (Datexco Company S.A., 2015, p. 11). As a consequence, the devices found at PVDs are up-to-date in order to fulfill this use. Even though KVDs have the same tools, people live far away from them, therefore, they will not attend a KVD as frequently as a PDVs.

Regardless KDVs and PVDs emerged as a need to fulfill the necessities of the community in rural settings, school continues being subject to external factors. As a clear example, at rural schools and its different branches, students have certain equipment that were given to them as a donation by Computadores para Educar Program (hereafter CPE due to its acronym in Spanish). These devices are computers and tablets that are meant to be used by students at school. However, its use is restricted because of the issues already mentioned before: lack of adequate connectivity, updates for tablets at schools, and lack of proper device maintenance. For obvious reasons, the need of implementing a rural policy is evident due to the aspects mentioned previously. 
ICT and the Foreign Language Learning

Celebic and Rendulic defined ICT in the following manner, "The acronym ICT (Information and Communication Technology) includes all technical means that are used for handling information and facilitating communication, including computers, networkhardware,communicationlines and all the necessary software" (p. 17). Likewise, "ICT stands for 'Information and Communication Technologies' ICT refers to technologies that provide access to information through telecommunications" (Christensson, 2010). These authors demonstrate the reasons why ICTs have become significant at a governmental level. It promotes the search for knowledge through the use of new technologies and the interaction with the internet. The implementation of communication technologies have become a policy for countries like Colombia, which promote the use of these technologies with the objective of accessing information on the net.

Keeping in mind that "The potential and promise of ICT use in education is clear: When implemented correctly, software in the classroom, for example, can allow students to learn at their own pace" (Trucano, n.d), ICT implementation can be empowering for students. Giordano (as cited in Mafuraga and Moremi, 2017, p. 145), pointed out that for learners to be equipped with ICT literacy and be lifelong learners, ICTs must successfully be integrated into both the English Language curriculum and general academic practices. Looking at the previous statement, there must be a connection among academic practices and the daily uses of ICT. However in our case, it is necessary to emphasize that it is difficult to connect them because at school, technology itself has inconsistencies when trying to implement new technologies in rural settings.

Using ICT as a tool ensures that learners have access to relevant information by using the internet. When the internet was first made available, there were only few nodes that were connected across the United States (Palermo and Cox, 2014). Back then, it was hard to imagine how technology would drastically change language learning and teaching. For example, e-mail was scarcely available at the beginning of the digital era, but it eventually opened up the possibility to communicate with others around the world. Thus, e-mail aided in connecting people drastically. Another example would be Tandem, a methodology which permitted the interaction between two language learners in order to practice language and give feedback to each other. "These diverse activities aim to advance internationalization by enabling students to develop their language and intercultural communication skills" (Batardière and Jeanneau, 2015, p. 289-290). Language learning could be done without leaving one's country, which consequently introduced culture to learning, making it more meaningful.

Multimedia, which is "the field concerned with thecomputer-controlled integration of text, graphics, drawings, still and moving images (Video), animation, audio, and any other media where every type of information can 
be represented, stored, transmitted and processed digitally" (Marshall, 2001), aids in education in the same as emailing aids in communication. They are the tools required for its success. It helps many educational fields, but in this case specifically, it helps in the acquisition of a foreign language. Even better, the way it is used in classrooms has allowed for the development of different class strategies and the increase of language skills, such as listening, writing, and speaking (Tri and Nguyen, 2014).

Thanks to the growth of the internet and technology applications, we keep changing the way we live and how we appreciate the world around us. The cybernetic world, spawned virtually, works as a bridge for education and culture, but it also plays a crucial role for the development of content used in the language teaching. Keeping in mind that students need to be constantly motivated to learn a foreign language, technology and ICTs have contributed to this in a very important way. There are so many new methodologies and strategies that help in the teaching/ learning process, such as blended learning. According to Garrison and Kanuka (2004), "blended learning is the thoughtful integration of classroom face-to-face learning experiences with online learning experiences" (p. 96).

Other efficient methods are Computer Mediated Communication (CMC). "Computer-mediated communication (CMC), such as chat, email, bulletin boards, and blogs, has been considered a facilitator of interactive communication for language learning" (Hirotani, 2009, p. 413). Another method would be Computer Assisted Language Learning (CALL), which has become efficient tools as a result of the many uses that computers provide. "Today we have not only computers of almost incomprehensibly greater power and sophistication but also a far greater range of consumer technologies that can be harnessed for language teaching and learning" (Garret, 2009, p. 719) Yet another method is Mobile Assisted Language Learning (MALL). According to Miangah and Nezarat (2012), "The rising speed of mobile technology is increasing and penetrating all aspects of the lives so that this technology plays a vital role in learning different dimensions of knowledge" (p. 315). These methodologies can be used in rural environments for learning a foreign language, where factors such as connectivity to the network and hardware conditions allow appropriate access to the required websites. Thanks to the fact that these virtual contents become easily accessible for foreign language learners in rural environments, learning becomes more meaningful because students can make connections with an existing reality.

Given this point, it is important to highlight that foreign language learning has a massive tool that allow users to be able to meet new cultures and real users of the language through ICTs. On that note, Scarino and Liddicoat (2009) state "Language is not a thing to be studied but a way of seeing, understanding and communicating about the world and each language user uses his or her language(s) differently to do this" (p. 16). Thus, many strategies can be implemented using computers with proper functionality of software 
and hardware. Putting this into the Colombian atmosphere, students who want to improve can use these technologies to do so by making a small investment and purchasing a program or paying for online courses.

Now, taking this option to the public education, the possibility for accessing foreign language content available around the world facilitates the labor of teachers. Likewise, it gives students an option for students to explore new things, which is hard to discover without the help of technology. Consequently, it is a requirement to know how to use these new technologies. "If used properly with clear educational objectives, CALL can interest and motivate learners of English" (Torut, 2000, p. 152). In this sense, a possible solution for this concern can be found in the implementation of ICTs in rural foreign language policies.

\section{The dilemma at school}

Given that schools are the most suitable place to instruct children in the new trends of innovation, they have been chosen to start an approach to technology and ICTs. Another attempt at promoting technology and ICTs is "Computers To Educate", which is "the National Government Program with the greatest social impact that generates equity through Information and Communication Technologies, promoting the quality of education under a sustainable model" (Computadores Para Educar, 2017). CPE bases their motto on three axes: Usage that cares about environmental issues related to computer waste, access that allows students to approach contents for strengthening education, and ownership that grants training for teachers. Image 3 shows the CPE webpage, which awards teachers who receive training and are given tablets in the different municipalities.

Understood as one of the four entities taking part in $\mathrm{CPE}$, the Ministry of Education oversees the pedagogical part of the program (Departamento Nacional de Planeación, 1999). In addition, CPE has the authority to decide what institutions can be benefited with new equipment given to schools. Likewise, CPE has as a main goal, which is to support human resources at school by adapting hardware to accommodate different school lessons. Consequently, educators are driven to develop strategies in order to include new technologies in their classes.

On one hand, the reality shows something different. It is necessary to mention that the number of computers and tablets is not enough and lack software updates. This situation was heard about in informal talks with teachers, who found it troublesome to work with these donated items in the second semester of 2017. At the beginning of the plan, the four entities were in charge of specific tasks during the implementation of the program. The MinTIC was in charge of technical aspects. The Departamento Nacional De Planeación oversaw administrative assessment and experience in the field of public and private branches. MEN, as said before, is in charge of the pedagogical aspect and educative managing, and the National Training 
Service (SENA) supervised the appropriateness and preparation of the equipment itself (Departamento Nacional de Planeación, 1999). In this case, SENA had the obligation of

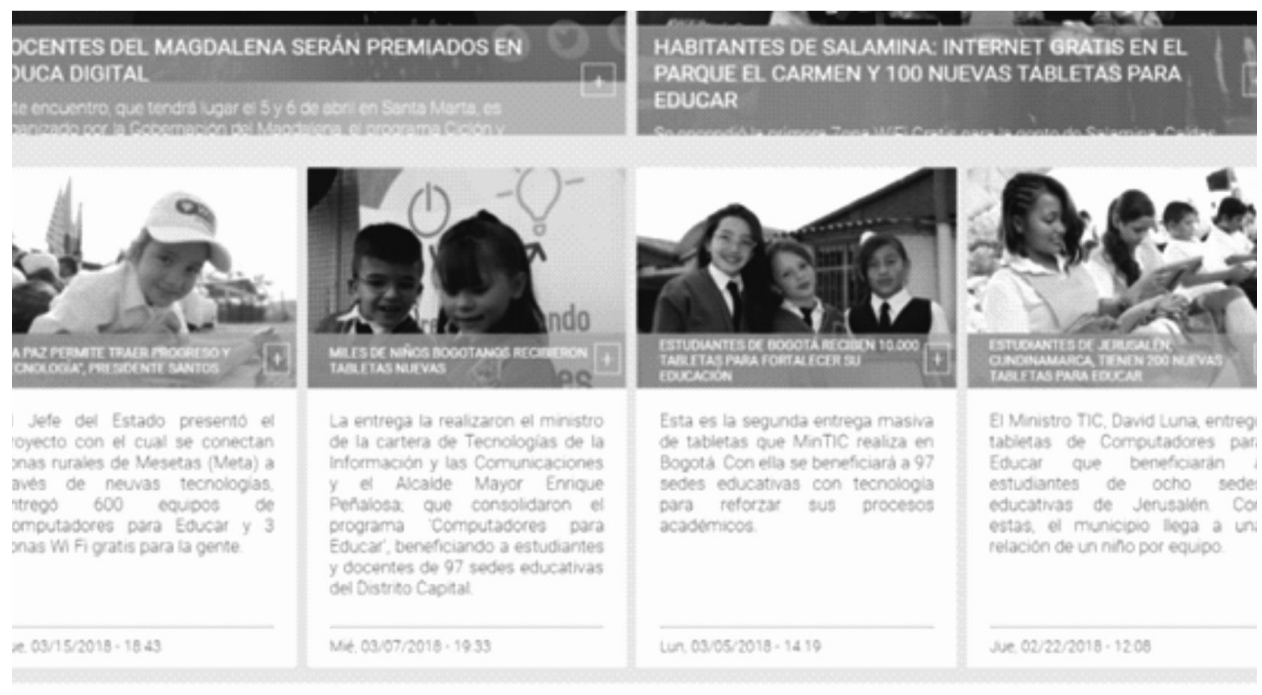

providing adequate instruction to the staff in charge of the equipment to be used.

Image 3. Awards given to teachers who complete training and receive tablets.

Source: CPE web page

This is a critical point where the new CPE association is having trouble. Training is missing or very limited, and a limited number of devices are being provided. This contradicts what the government keeps promoting on its webpage as shown by Image 3. Undoubtedly, when these kinds of shortcomings are presented, the outcomes will not be as expected, but rather there will be deferral in the implementation of the program.

In addition to the efforts made by the government, the computers and tablets must have valid software to function. Nevertheless, these computers and tablets do not have the necessary updates or applications that are needed for classes. This is the main reason electronic hardware at schools is becoming obsolete or simply inadequate. Therefore, the intention of maintaining the hardware is unfulfilled due to the lack of updated and adequate equipment. The MEN are constantly promoting training14 to teachers with $^{\text {h }}$ the goal of using technology at schools and gaining a competitive edge in ICTs (Ministerio de Educacion Nacional, 2009; Universia, 2012; MinTIC, 2015). This is in direct contrast to facts from the CPE webpage, which are shown in Image 4.

14 Initial training is understood as the time devoted to learn how to use the hardware. 


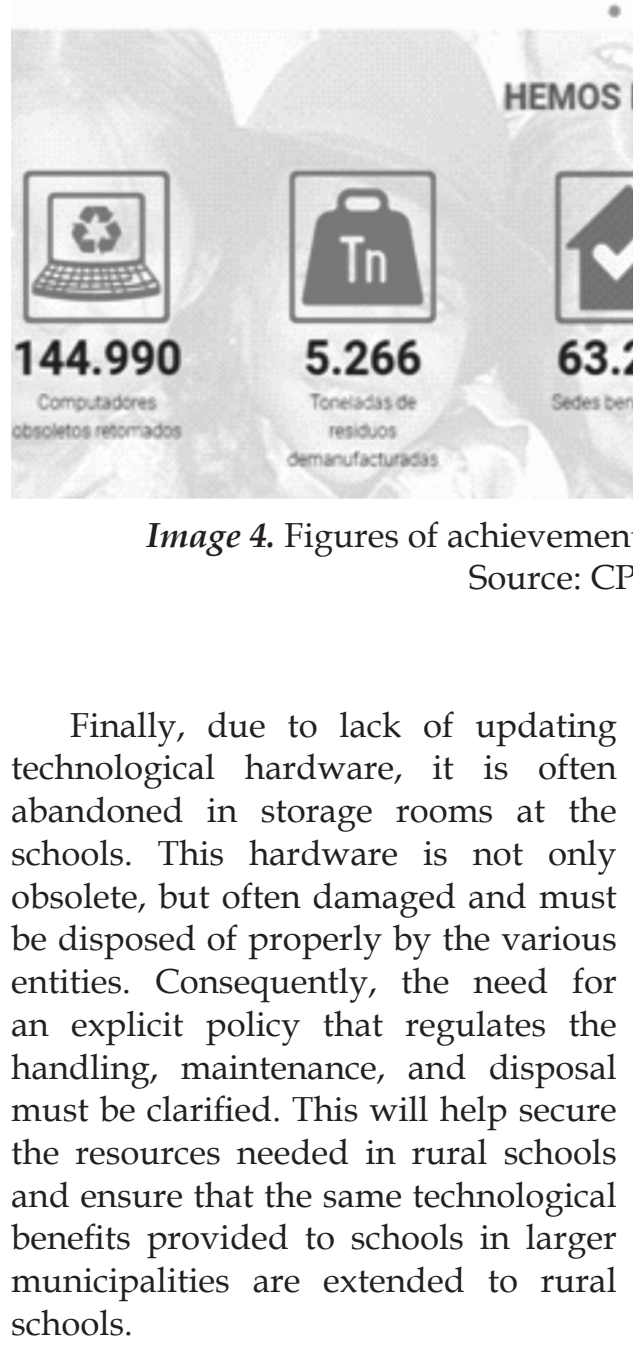

\section{Conclusions}

Theuse of ICT inanacademic context is undeniable. Its regulations allow most citizens living in cities the ability to use technology for communication. This extends into education, where it is most commonly used in the places

15 Evidently, the figure shows a big number of trainees. Nevertheless, it does not state where it has taken place and who the benefactors are. Retrieved from: http://www.computadoresparaeducar.gov.co/es where there are connectivity issues. Although both rural and urban schools have Information Technology classes, both school settings need to receive updated technology in a uniformly distributed manner.

Although there are protocols for the regulation of ICTs in education, there is also a need to review the viability for having an ICT language education policy in urban and rural settings. This also ensures that teachers will be informed about the latest information and innovations, allowing teachers to persuade rural students to stay in school. This benefits rural students by strengthening their technological skills relevant to today's society. It is a well-known fact that new technologies used in the classroom allow teachers to develop more innovative lesson plans.

Policy making, once again, could be a promising solution to overcome these situations. "Education policymakers and planners must first of all be clear about what educational outcomes are 
being targeted" (Tinio, 2003, p.11). Nonetheless, having such a policy does not mean that the problem will be resolved, but it can be useful in achieving governmental objectives.

Foreign languages particularly excel with technology, as there are lots of great resources that can help students learn a second language using technology in the classroom. However, as mentioned before, creating a learning environment through ICT requires that external factors, other than the teacher's pedagogy or ICT training, are taken care of. One of these external factors is the lack of constant connectivity or no connectivity at all. Another is the use of a limited amount of equipment due to poor maintenance or obsolescence. This results in having to share technology meant for individual use.

As seen in "Computadores Para Educar", the distribution and maintenance are facets of the government's goals to implement technology in areas where internet and technology are not easily accessible. Therefore, this ensures that all Colombian students will have identical conditions to learn each educational subject.

Students that use ICT tools in the classroom must deal with several issues. One of the main issues is the use of unsuitable computers, which diminish the possibilities of success in learning a foreign language using ICT tools. In addition to this, the use and navigation of webpages are also something new for them, and it must be taught.

The Ministry of Communication and Technologies must look at other possibilities to implement ICTs in rural settings, which include accessibility and connectivity. One suggestion is to provide residents living in a rural setting with smart phones. Miangah and Nezarat (2012) suggested that "As mobile phones with high capabilities extend into all areas of human life, it is expected that this wireless computing device soon becomes accessible for all urban and rural areas of each country" (p. 309). More importantly, since students are using smartphones to chat more frequently than before, MALL can be adapted in schools to use it as a means for learning a language.

The scope of ICT tools in rural Colombian schools is vast and important to many students. The problem lies in the lack of updated equipment and applications relevant to students' learning. Without basic maintenance and training to provide the necessary service to this equipment, the true benefits cannot be accurately measured.

\section{References}

Barley, Z. A., and Brigham, N. (2008). Preparing teachers to teach in rural schools (Issues \& Answers Report, REL 2008-No. 045). Washington, DC: U.S. Department of Education, Institute of Education Sciences, National Center for Education Evaluation and Regional Assistance, Regional Educational Laboratory Central. Retrieved from http://ies.ed.gov /ncee/edlabs.

Batardière, M., and Jeanneau, C. (2015). Facilitating a face-to-face 
tandem language exchange on a university campus. Studies in Self-Access Learning Journal, 6(3), 288-299.

Bonilla, S.X., and Cruz-Arcila, F. (2014). Critical socio-cultural elements of the intercultural endeavour of English teaching in Colombian rural areas. Profile Issues in Teachers Professional Development, 16(2), 117-133.

Bonilla Carvajal, C. A., and TejadaSánchez, I. (2016). Unanswered questions in Colombia's foreign language education policy. Profile Issues in Teachers' Professional Development, 18(1), 185-201.

Celebic, G., and Rendulic, D. I. (2011). IT desk. Info-project of computer e-education with open access. Retrieved from http://www. itdesk.info/handbook_basic_ict_ concepts.pdf

Christensson, P. (2010, August 26). TechTerms. ICT Definition. Retrieved from https:// techterms.com/definition/ict

Colombia ya cuenta con 500 zonas wifi gratis (2017, June 4). El Tiempo. Retrieved from http://www. eltiempo.com/colombia/otrasciudades/colombia-llega-hoy-a500-zonas-wifi-gratis-95276

Computadores para educar (2017). ¿Qué es Computadores para Educar? Retrieved from http://www. computadoresparaeducar. gov.co/es/nosotros/que-escomputadores-para- educar
Congreso De La República De Colombia. (2009). Ley No 1341 de 30 de julio de 2009. Retrieved from http:/ / www.mintic.gov.co/ portal/604/w3-article-3707.html

Datexco Company S.A. (2015). Estudio, uso y apropiación de las TIC en Colombia. Retrieved from https://www.mintic.gov.co/ portal/604/articles-15296_ recurso_3.pdf

Decreto Ley 0019, (2012). Retrieved from http:/ / www.secretariasenado. gov.co/senado/basedoc/ decreto_0019_2012.html

Departamento Nacional de Planeación (1999). Documento Conpes 3063, Consejo Nacional De Política Económica y Social. Programa de donación masiva de computadores a colegios públicos "Computadores para Educar". Retrieved from http://www. computadoresparaeducar.gov. co/sites/default/files/inlinefiles/Conpes_3063.pdf

Departamento Nacional de Planeación. (2013). Documento Conpes 3769 Consejo Nacional de Política Económica y Social. Declaratoria de Importancia Estratégica de los Proyectos "Ampliación Programa de Telecomunicaciones Sociales" E "Implementación 800 Tecnocentros Nacional". Retrieved from https://www.notinet. com.co/descargar_archivo. php?idinv $=262770$

Garrett, N. (2009). Computer assisted language learning trends and issues revisited: Integrating 
innovation. The Modern Language Journal, 93, 719-740.

Garrison, D. R., and Kanuka, H. (2004). Blended learning: Uncovering its transformative potential in higher education. The Internet and Higher Education, 7, 95-105.

Hirotani, M. (2009). Synchronous versus asynchronous CMC and transfer to Japanese oral performance. CALICO Journal, 26(2), 413-438.

Karpati, A. (2011). Digital literacy in education. UNESCO Institute for Information Technologies in Education. Retrieved from http://iite. unesco. org/ publications/3214688.

Lankshear, C., and Knobel, M., (2011) New literacies: everyday practices and social learning, 3rd edition. Open University Press, Maidenhead, UK.

Mafuraga, M., and Moremi, M. (2017). Integrating Information and Communication Technology in nglish Language teaching: A case study of selected Junior Secondary Schools in Botswana. International Journal of Education and Development Using Information and Communication Technology, 13(1), 142-152.

Marshall, D. (2001). What is multimedia? Retrieved from https://users. cs.cf.ac.uk/Dave.Marshall/ Multimedia/node10.html

Mercado, B. (2017). Análisis: ¿cómo superar la crisis de educación en el campo colombiano?
Revista Semana. Retrieved from https://www.semana.com/ nacion/articulo/panoramade-la-educacion-en-el-campocolombiano/531885

Miangah, T. M., and Nezarat, A. (2012). Mobile-assisted language learning. International Journal of Distributed and Parallel Systems, 3(1), 309.

Ministerio de Educación Nacional (MEN). (2009). MAESTROS competentes. Al tablero. Retrieved from https://www. mineducacion.gov.co/1621/ article-195576.html

Ministerio de Educación Nacional (MEN). (2002). Decreto 3020. Retrieved from https://www. mineducacion.gov.co/1621/ articles-104848_archivo_pdf

Ministerio de Educación Nacional (MEN). (2001). Más campo para la educación rural. Al tablero. Retrieved from https://www. mineducacion.gov.co/1621/ article-87159.html

Ministerio de las Tecnologías y la Información (MinTIC). (2018). Ecosistema digital: infraestructura. Retrieved from http:/ / www.mintic.gov.co/ portal/vivedigital/612/w3propertyvalue-630.html

Ministerio de las Tecnologías y la Información (MinTIC). (2018). Kioskos vive digital. In Colombia tic portal de estadísticas del sector. Retrieved from http:// 
colombiatic.mintic.gov.co/679/ w3-propertyvalue-36365.html

Ministerio de las Tecnologías y la Información (MinTIC). (2015). Vive Digital Colombia 2014-2018. Retrieved from https://www. mintic.gov.co/portal/604/ articles-5193_recurso_2.pdf

Palermo, E., and Cox, L. (2014). Who invented the internet? Livescience. Retrieved from https://www. livescience.com/42604-whoinvented-the-internet.html

Padilla, J., Vega, P., and Rincón, D. (2014). Tendencias y dificultades para el uso de las TIC en educación superior. Entramado, 10(1), 272-295.

Perfetti, M. (2004). Estudio sobre la educación para la población rural en Colombia. Retrieved from http:// red-ler.org/informes.htm

Ramos-Holguín, B., and AguirreMorales, J. (2016). English Language Teaching in rural areas: A new challenge for English Language Teachers in Colombia. Cuadernos de Lingüística Hispánica, (27), 209-222.

Scarino, A., and Liddicoat, A. (2009). Teaching and learning languages: A guide. Melbourne: Curriculum Corporation.

Servon, L. (2002). Bridging the digital divide: Technology, community and public policy. Blackwell publishing.
Tinio, V. (2003). ICT in Education. Retrieved from https://akgul. bilkent.edu.tr/egitim/eprimeredu.pdf

Torut, B. (2000). Computer-assisted language learning: An overview. Silpakorn University International Journal, 1(1), 131-153.

Tri, D., and Nguyen, N. (2014). An exploratory study of ICT use in English language learning among EFL university students. Teaching English with Technology, 14(4), 32-46.

Trucano, M. (n. d.) Technology and Innovation in Education. Retrieved from https://www.worldbank. org/en/topic/edutech

Universia (2012, April 4). Docentes serán capacitados en TICs. Retrieved from http://noticias. universia.net.co/ciencia-nn-tt/ noticia/2012/04/04/921677/ docentes-seran-capacitados-tics. html

Uribe, A., and Machett, L. (2010). Information literacy in Colombia: Report of the state of the art. Retrieved from https:// www.ifla. org/files/assets/informationliteracy/publications/il-report/ colombia-2010-en.pdf 